INSTITUTE FOR DEFENSE ANALYSES

\title{
Review of the Fiscal Year 2014 (FY14) Defense Environmental International Cooperation (DEIC) Program
}

\author{
Susan L. Clark-Sestak
}

May 2015

Approved for public release; distribution is unlimited.

IDA Document D-5413

Log: H 15-000320

INSTITUTE FOR DEFENSE ANALYSES 4850 Mark Center Drive Alexandria, Virginia 22311-1882 


\section{Report Documentation Page}

Form Approved

OMB No. 0704-0188

Public reporting burden for the collection of information is estimated to average 1 hour per response, including the time for reviewing instructions, searching existing data sources, gathering and maintaining the data needed, and completing and reviewing the collection of information. Send comments regarding this burden estimate or any other aspect of this collection of information,

including suggestions for reducing this burden, to Washington Headquarters Services, Directorate for Information Operations and Reports, 1215 Jefferson Davis Highway, Suite 1204, Arlington

VA 22202-4302. Respondents should be aware that notwithstanding any other provision of law, no person shall be subject to a penalty for failing to comply with a collection of information if it

does not display a currently valid OMB control number.

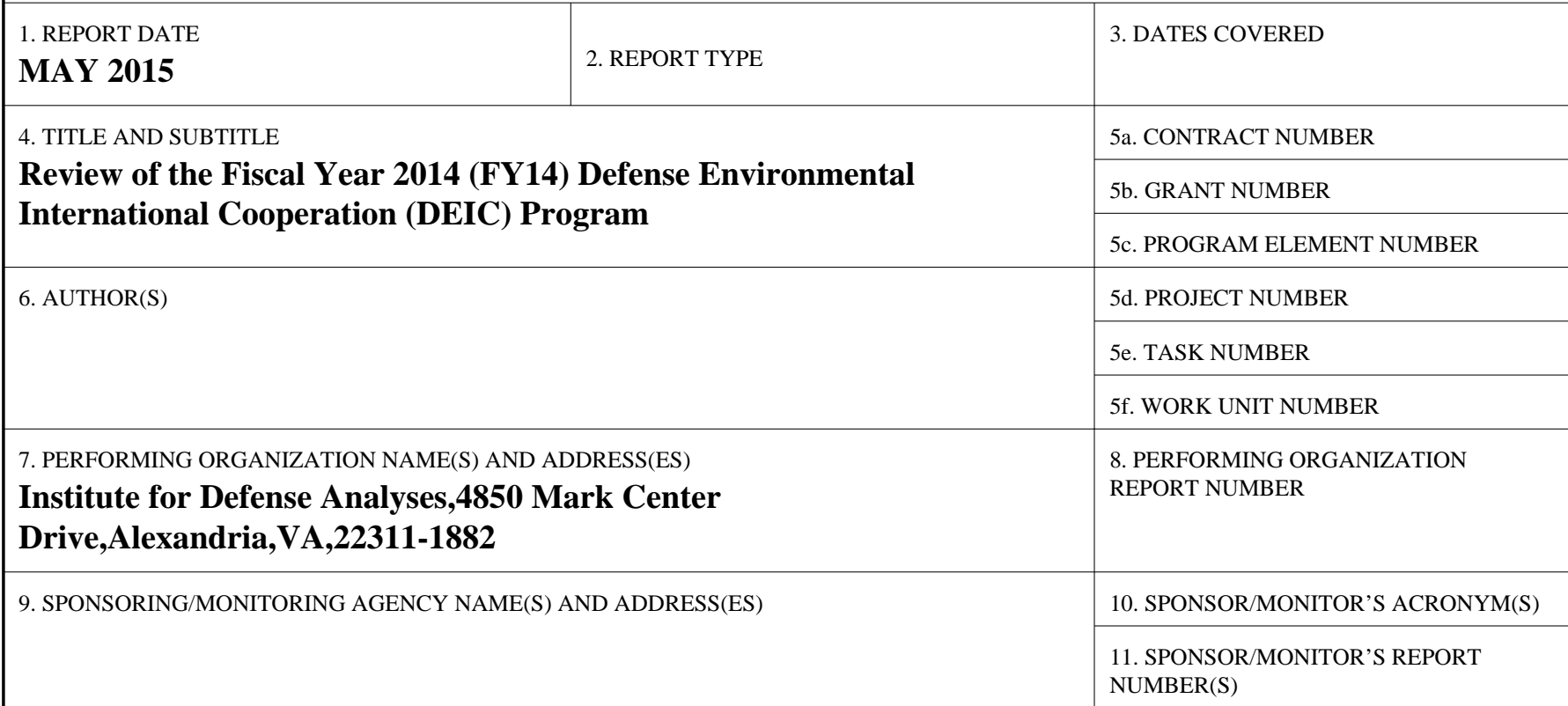

12. DISTRIBUTION/AVAILABILITY STATEMENT

Approved for public release; distribution unlimited.

13. SUPPLEMENTARY NOTES

14. ABSTRACT

The Defense Environmental International Cooperation (DEIC) program is a tool for the Office of the Secretary of Defense and the Combatant Commands (CCMDs) to use as part of their security cooperation engagement activities with other nations. The projects it supports focus on defense-related, environmental themes, with special priority on projects that promote mission sustainment, innovative approaches to environment, safety and occupational health (ESOH) risk management, and/or building capacity for strategic partnerships. IDA reviewed the execution of the Fiscal Year 2014 (FY14) DEIC program, assessed the program's performance for that year, and recommended metrics to evaluate and changes to implement to enhance the program's future execution.

15. SUBJECT TERMS

16. SECURITY CLASSIFICATION OF:

a. REPORT

unclassified b. ABSTRACT unclassified c. THIS PAGE unclassified
17. LIMITATION OF ABSTRACT

\section{NUMBER \\ OF PAGES}

54 19a. NAME OF RESPONSIBLE PERSON 
The Institute for Defense Analyses is a non-profit corporation that operates three federally funded research and development centers to provide objective analyses of national security issues, particularly those requiring scientific and technical expertise, and conduct related research on other national challenges.

About This Publication

The work was conducted by the Institute for Defense Analyses (IDA) under contract W91WAW-12-C-0017, Project AM-6-2557, "International Defense Environmental Cooperation," for the Office of the Deputy Under Secretary of Defense for Installations and Environment, Environmental Readiness and Safety [ODUSD(I\&E/ERS)]. The views, opinions, and findings should not be construed as representing the official position of either the Department of Defense or the sponsoring organization.

Acknowledgments

The IDA Technical Review Committee consisted of Dr. Alison Lawrence.

Copyright Notice

(C) 2015 Institute for Defense Analyses

4850 Mark Center Drive, Alexandria, Virginia 22311-1882 • (703) 845-2000.

This material may be reproduced by or for the U.S. Government pursuant to the copyright license under the clause at DFARS 252.227-7013 (a)(16) [Jun 2013]. 


\title{
INSTITUTE FOR DEFENSE ANALYSES
}

IDA Document D-5413

\section{Review of the Fiscal Year 2014 (FY14) Defense Environmental International Cooperation (DEIC) Program}

\author{
Susan L. Clark-Sestak
}





\section{Executive Summary}

The Defense Environmental International Cooperation (DEIC) program is a tool available for the Office of the Secretary of Defense and the Combatant Commands (CCMDs) to use in security cooperation engagement activities with other nations. The projects it supports focus on defense-related environmental themes, with special priority placed on projects that promote the sustainment of mission capability and interoperability and the creation and enhancement of strategic partnerships and partner capabilities. The Institute for Defense Analyses reviewed the execution of the FY14 DEIC program within each of the CCMD areas of responsibility and assessed the overall program's performance for that year. This document has three purposes. First, it serves as a record of what was accomplished during FY14 under the DEIC program. Second, it raises awareness about the program's activities throughout the world among the CCMD leads for DEIC (and other interested personnel), thereby enhancing the cross-pollination of ideas and products developed under the DEIC program's auspices. Third, it offers a set of metrics for evaluating the program as well as recommendation to further enhance the program's effectiveness, primarily related to timing and funding issues.

For FY14, the DEIC program had a final budget of \$1.691 million. A three-member Advisory Group reviewed proposals totaling $\$ 4.730$ million and then recommended to the Deputy Under Secretary of Defense for Installations and Environment how these funds should be allocated. Of note, despite the small amount of funding and the challenges of executing an international program with funding available only incrementally, DEIC's reach was extensive. Some 500 representatives from 57 nations participated in DEICfunded activities over the course of the year, and the program leveraged almost another \$1 million in other sources of funding to execute these projects. 



\section{Contents}

1. Overview of the Defense Environmental International Cooperation (DEIC) Program and FY14 Execution ................................................................................1

A. The FY14 DEIC Program.............................................................................

B. Current Program Realities .................................................................................6

2. U.S. Africa Command (AFRICOM) Execution of DEIC Projects .............................7

3. U.S. Central Command (CENTCOM) Execution of DEIC Projects..............................9

4. U.S. European Command (EUCOM) Execution of DEIC Projects ............................11

5. U.S. Northern Command (NORTHCOM) Execution of DEIC Projects....................15

6. U.S. Pacific Command (PACOM) Execution of DEIC Projects.................................17

7. U.S. Southern Command (SOUTHCOM) Execution of DEIC Projects .....................19

8. Global and Program Support Projects Executed under the DEIC Program ...............21

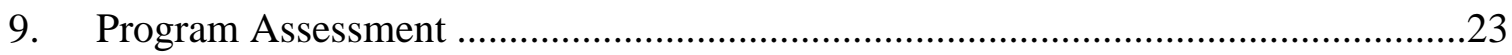

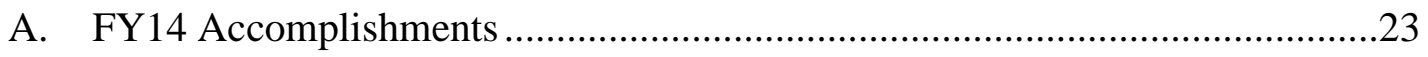

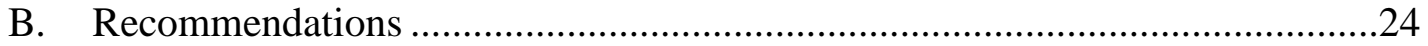

Appendix A. DEIC FY14 Call for Proposals and Meeting Participation ........................ A-1

Appendix B. DEIC FY14 Spreadsheet ……………….............................................

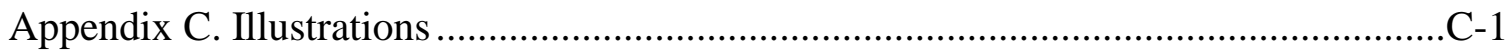

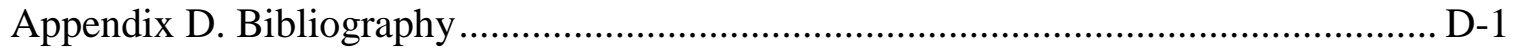

Appendix E. Abbreviations................................................................................ 



\section{Overview of the Defense Environmental International Cooperation (DEIC) Program and FY14 Execution}

In previous assessments of the DEIC program, the Institute for Defense Analyses (IDA) described the purposes of DEIC, the types of activities it has funded, and the submission and approval processes for the program. ${ }^{1}$ This document focuses on the execution of the FY14 program and identifies current challenges to project and program execution, as well as opportunities to address some of these challenges.

\section{A. The FY14 DEIC Program}

Residing within the Environment, Safety, and Occupational Health (ESOH) office of the Deputy Under Secretary of Defense for Installations and Environment (DUSD(I\&E)), ${ }^{2}$ the DEIC program was originally funded in FY14 at \$2,037,000. By the conclusion of the fiscal year, the actual program budget was $\$ 1,691,000$. The final budget was thus 17 percent less than DEIC's original planned budget. In addition, as of March 2015, a total of $\$ 26,146.81$ was returned (or planned to be returned) to I\&E by the Combatant Commands (CCMDs). The reasons for the returns varied by CCMD and are described in Table 1. In the final analysis, the total amount of funding executed under the DEIC program in FY14 was $\$ 1,667,753.19$.

Table 1. DEIC Program Funding Returned, by CCMD, and Reasons for Return

\begin{tabular}{lrll}
\hline \multicolumn{1}{c}{ CCMD } & Amount Returned & & \multicolumn{1}{c}{ Reason } \\
\cline { 1 - 1 } $\begin{array}{l}\text { Northern } \\
\text { Command }\end{array}$ & $\$ 22,182.73$ & & $\begin{array}{l}\text { Funding not available when needed due to Continuing } \\
\text { Resolution, so one project could not be executed at } \\
\text { the required time. }\end{array}$ \\
Southern & $\$ 1,343.83$ & $\begin{array}{l}\text { Difference in program execution versus estimated } \\
\text { cost. }\end{array}$ \\
\hline
\end{tabular}

1 Most recently, see Susan L. Clark-Sestak and Ashley Neese Bybee, Review of the Fiscal Year 2013 (FY13) Defense Environmental International Cooperation Program. D-5129, Alexandria, VA: Institute for Defense Analyses, February 2014.

2 The office of DUSD (I\&E) has since been reorganized. It is now the Office of the Assistant Secretary of Defense for Energy, Installations and Environment (ASD(EI\&E)). 
Over the last several years, the Federal Government's Continuing Resolution (CR) has had a negative impact on the consistency with which DEIC program funds can be made available; FY14 was no exception. As Figure 1 illustrates, less than one-quarter of the funds were available to the CCMDs in the first quarter, and more than half of the funds were not available until at least the end of the second quarter. ${ }^{3}$ Moreover, neither AFRICOM nor NORTHCOM received any funding until March 2014. As a result, it was extremely difficult for the CCMDs to execute many of their proposed projects, no matter how wellplanned their schedules were.

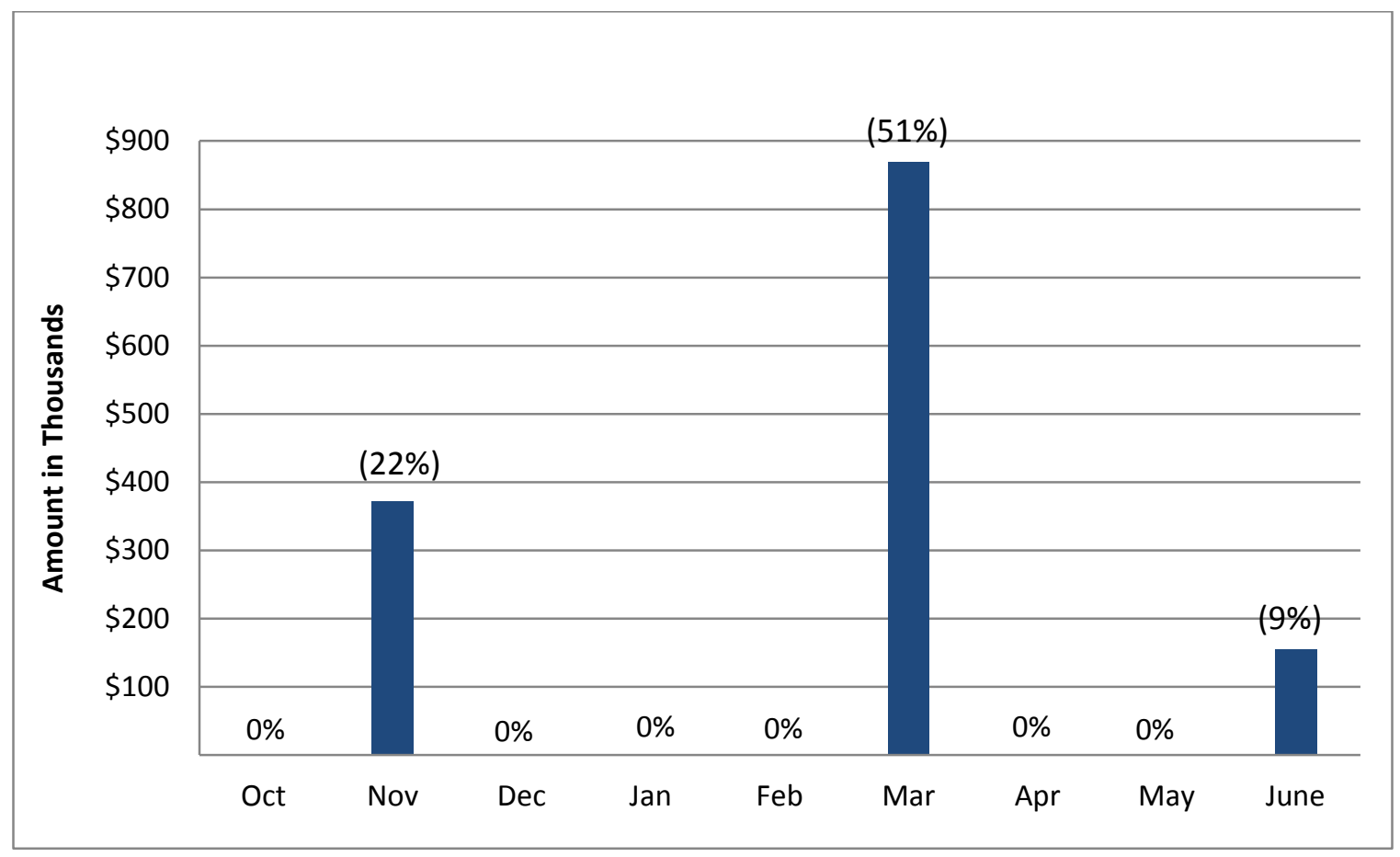

Figure 1. Amount and Timing of DEIC Funds Released to the CCMDs (Thousands)

3 Numbers do not add to 100 percent (or $\$ 1,691,000$ ) because they do not include funding to support overall DEIC program execution, totaling \$296,900. 
The DUSD(I\&E) released the FY14 Call for Proposals and Meeting Participation in May 2013 (Appendix A), which provided guidance on the DEIC program's priorities. The project proposals submitted for the DEIC Advisory Group's consideration totaled $\$ 4,730,000$, of which the Advisory Group found $\$ 3,590,000$ to be valid requirements appropriate for DEIC funding. The size of the requested amount continues to prove that the CCMDs have requirements and interests in DEIC activities well in excess of the available budget. Figure 2 illustrates this long-standing trend.

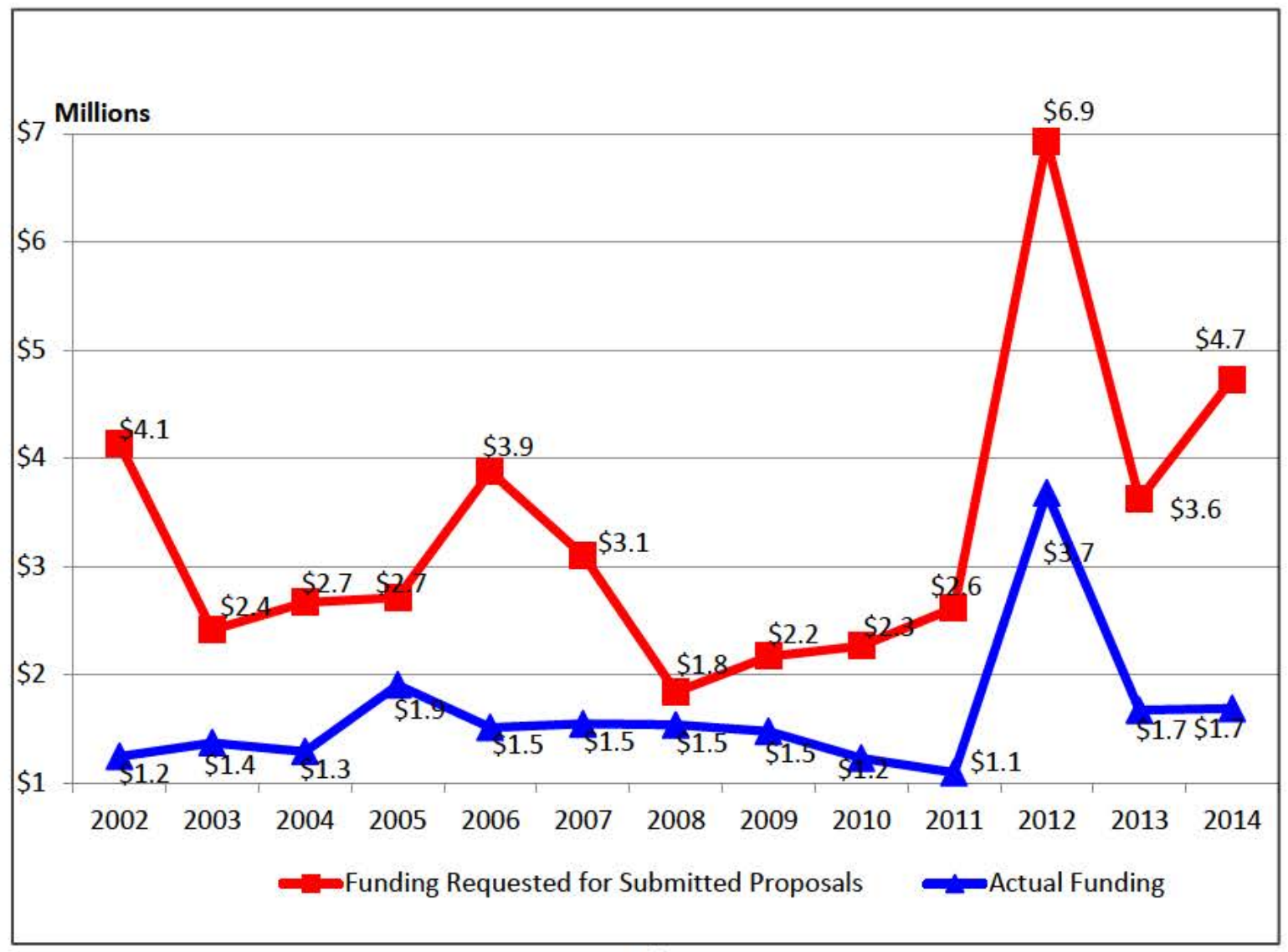

$\mathrm{S}$

Figure 2. DEIC Annual Funding Levels: CCMD Requests vs. Actual

Appendix B contains the spreadsheet listing all projects submitted for DEIC consideration. As in previous years, the Advisory Group continued the approach of identifying those projects that should have the highest priority (their funding is listed in the "approved" column of the spreadsheet) along with those also deemed valid but with lower priority (listed in the "reconsider" column). Other projects (with no funding listed in either column) were not deemed appropriate for DEIC funding by the Advisory Group. In addition to the guidance provided in the call for proposals memorandum (see Appendix A), a number of factors were considered during the Advisory Group meeting when determining a project's category, but these factors are not specifically prioritized since their 
applicability and prominence can vary by topic, country, and region. These criteria are routinely addressed during the Advisory Group's discussions with each of the CCMDs. They include (but are not limited to) the following:

- The level of "interest" the CCMD (or Office of the Secretary of Defense (OSD)) has in engaging with the given country, which draws on the CCMD's Theater Security Cooperation (TSC) plans and other relevant DOD and national-level documents

- The extent to which the engagement opens opportunities for a new or expanded relationship with that country (or, on the contrary, whether there are already so many activities with the country that this effort would have little perceptible impact)

- The project's ability to contribute to interoperability and/or mission sustainment

- The involvement of host nation defense personnel in the project. (While the involvement of additional agencies is welcomed —indeed, desirable - the participation of defense personnel (either uniformed or civilian) is a necessity)

- The potential for the project to contribute to the host nation's ability to serve a regional leadership role

- Where the project ranks in the CCMD's own prioritization of its proposals (each CCMD must rank order all proposals it has submitted)

- The perceived ability of the CCMD and host nation to execute the project as proposed

- A balance of projects and funding across the CCMDs, taking many of the above factors into consideration

The Advisory Group's recommended funding for projects in the first column totaled approximately 80 percent of the original budget, a decision driven (as in previous years) by anticipated budget cuts and the challenges imposed by operating under the CR. If one of these projects could not be executed for any reason, the Advisory Group had a range of valid "reconsider" projects from which to choose, thereby offering the flexibility to decide which projects were most likely to be executable within the remainder of the fiscal year. This proved an effective strategy again in FY14 as there was a 17-percent cut in DEIC's actual budget, and a number of projects had to be rescheduled or relocated often because of delayed funding and/or host nation considerations.

Figure 3 illustrates the allocation of funding by area of responsibility (AOR). The CCMD project summaries provided in chapters 2-8 of this document offer more detail on the program's funding and execution in FY14. Chapter 9 explains that the higher-thanusual funding level for program support was due mainly to increased support from a 
Federally Funded Research and Development Center (FFRDC) that participated as a subject matter expert in events. The after action reports (AARs), agendas, participant lists, and many of the presentations for each project have been captured and loaded onto the DEIC section under the international tab on the DOD Environmental Network and Exchange (DENIX) website. ${ }^{4}$

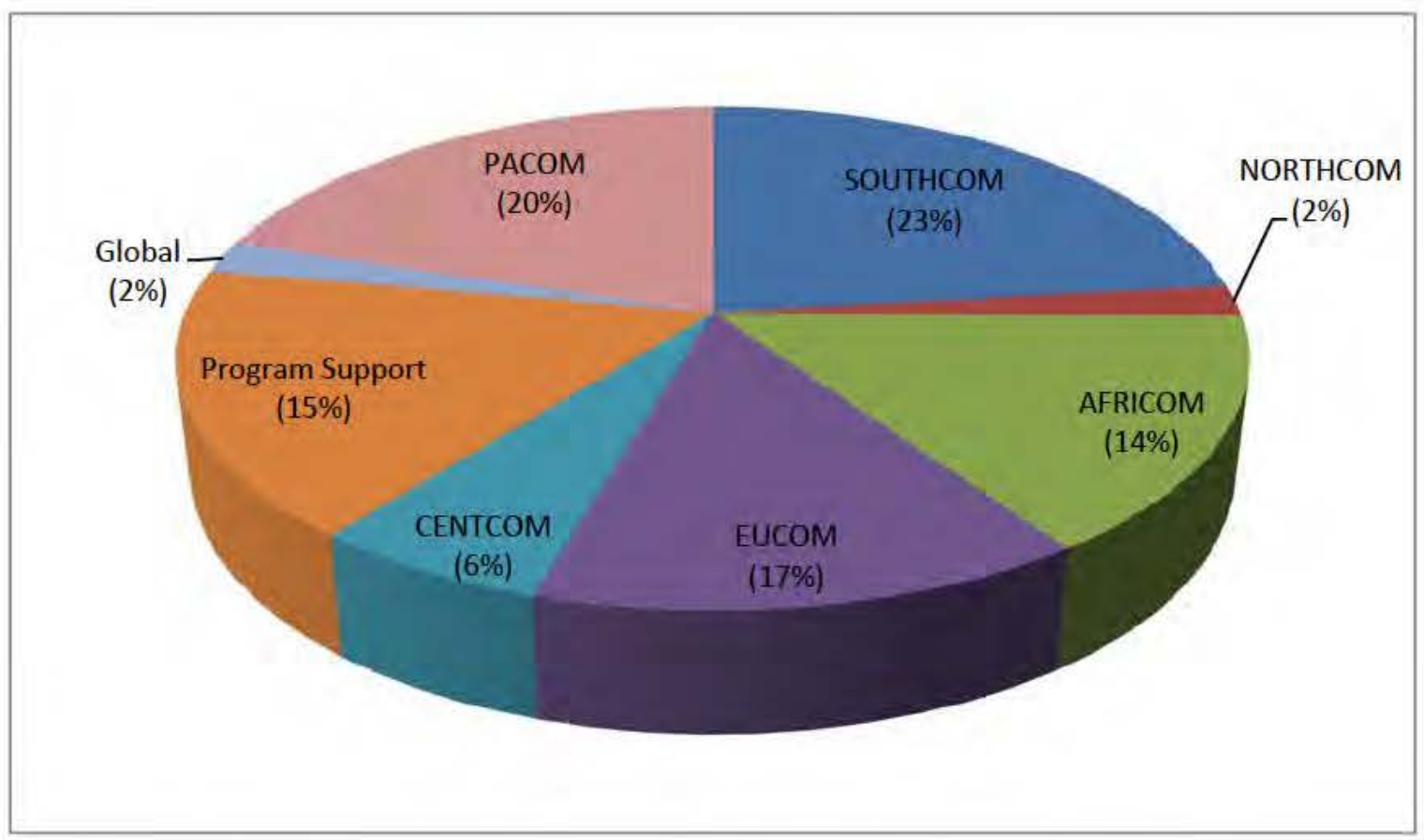

Figure 3. DEIC Program FY14 Spending, by Area of Responsibility

The projects in the following chapters are listed in the order in which they appear on the FY14 spreadsheet (see Appendix B). As described above, this spreadsheet lists all proposed projects by project number and title, the DEIC funds requested for each, the funding for approved projects, projects to be reconsidered, and the funding levels as actually executed ("Actual" column). Because in many cases funding sent to the CCMDs for these projects was supplemented by other funding sources, the spreadsheet also lists the amount and source of any such additional funding. Of note, across all the CCMDs, at least another $\$ 942,000$ in funding was used to help execute the approved DEIC projects. Of the twenty-seven DEIC projects representing executed events in FY14, fifteen of them (or 56 percent) utilized other sources of funding. This funding came from a wide variety of sources: Traditional Commander's Activity (TCA), Title 10, Asia Pacific Regional Initiative (APRI) program, U.S. Army Europe, U.S. Agency for International Development

4 The DEIC portion of the website is password-protected and accessible to members of the DEIC community. 
(USAID), United Nations Environmental Program (UNEP), Africa Center for Strategic Studies (ACSS), and U.S. Army Engineer Research and Development Center (ERDC). Leveraging additional funding sources is another indication of the value the CCMDs and other organizations attach to DEIC activities.

\section{B. Current Program Realities}

As noted earlier, CRs in the DOD budget have caused persistent delays in making funds available to those executing the DEIC program's activities. In an international program such as DEIC, which inherently involves collaboration with other governments and often with international organizations, such delays have directly resulted in the cancellation of planned projects because the U.S. government cannot make the necessary financial commitments on the required timeline. While these challenges are hardly unique to the DEIC program, it is an operating reality that has affected program results. But even if CRs continue there is a viable solution: fully fund the DEIC program under the first CR. First, within I\&E's portfolio, the DEIC budget is a small fraction of overall funding and could be fully funded in the first CR if I\&E's larger programs absorbed a relatively small additional cut during the CR. Second, DEIC represents a continuation of program activities, so its projects would not need to be characterized as a new start.

Another operating reality, this one specific to DEIC, is the reduction in OSD manpower dedicated to the program. Over the past two years, personnel changes have reduced OSD's visibility in the DEIC program, both internally and internationally. Given DOD's focus on the importance of phase zero operations (which includes security cooperation activities such as those supported by the DEIC program), DEIC would greatly benefit from a more robust commitment from OSD than it had during FY14. 


\section{U.S. Africa Command (AFRICOM) Execution of DEIC Projects}

DUSD(I\&E) approved \$235,000 in projects for the AFRICOM AOR and another $\$ 785,000$ in projects eligible for reconsideration. Actual funding for this AOR remained at the approved level of $\$ 235,000$ for the execution of six projects. The executed projects in the AFRICOM AOR and some of their key themes or findings are described below.

Togo-Gulf of Guinea Maritime Environmental Security Discussions (AFFY14006, \$52K). Held in July 2014, in Lome, Togo, this symposium covered topics such as global environmental security challenges, military-civilian stakeholder partnerships, environmental considerations in military operations, and environmental security aspects of addressing coastal erosion and phosphate mining effluent. The event was co-hosted with UNEP and brought together 35 military and civilian representatives from Togo and Benin, with the Ministers of Environment from both countries speaking at its opening session. This symposium grew out of the 2012 Environmental Security Forum hosted in Cote d'Ivoire, after which the U.S. embassy was asked by UNEP to focus on specific potential environmental issues in Togo and Benin. The symposium was important in helping to establish interagency relationships and to identify ways for their militaries to play a more active role in environmental management. One proposal on the latter issue advanced by the U.S. team, and embraced by the participants, was to retrain approximately 20 percent of the military force to address ecologically related infrastructure and construction projects; this is referred to as the "ECOFORCE" concept. In addition, there was agreement to create a bilateral environmental commission to improve cooperation and focus on cross-border environmental issues.

Ethiopia-East Africa Regional Environmental Security Symposium (AFFY14007, \$10K). While not all host nation approvals could be obtained and it therefore was not possible to execute the symposium in FY14, AFRICOM did hold a planning meeting and ultimately obtained high-level approval from the Government of Ethiopia to conduct a regional water security seminar in FY15, subject to the availability of U.S. funding. One specific topic of interest to the military there is the maintenance and repair of U.S.-provided field water treatment equipment.

Burkina Faso-West Africa Regional Environmental Security Symposium (AFFY14008, \$80K). Some 75 participants and speakers from Burkino Faso, Niger, Mali, and Ghana attended this symposium in August 2014 to increase awareness and exchange experiences among military and non-military representatives on various environmental 
security challenges in the region. Topics included global and regional perspectives on environmental security, climate change, water resources management, sustainability, and disaster risk management and emergency response. Here, too, the ECOFORCE concept was discussed and the Government of Niger has expressed interest in this training; indeed, the President of Niger has subsequently sent an official request to the U.S. embassy for AFRICOM support on this initiative.

South Africa-South/Central Africa Regional Environmental Security Symposium (AFFY14009, \$10K). Partnering with ACSS, ERDC, and the Stellenbosch Institute for Advanced Study, among others, AFRICOM co-hosted a strategic-level dialogue on water and security. The workshop included thirty experts from research institutions and international organizations across Africa who addressed topics such as the implications of climate variability for security in Africa, security-related dimensions of the water-energy-security nexus, and raising awareness of water security issues among all stakeholders - especially African military forces. Presentations focused on four key water basins with the resulting conclusions: falling water levels in Lake Chad have heightened insecurity in the Sahel; border disputes in Lake Victoria could trigger trans-national conflict; hydroelectric projects along the Nile River threaten sub-regional stability; and flow variability and pollution in the Congo River undermine human security. It was also noted that while militaries may not have a leading role in addressing all these issues, it is important to raise their awareness of these kinds of security factors.

Mauritius-Oil Spill Preparedness Discussions and Table Top Exercise (AFFY14011, \$49K). Originally scheduled to be held in Mauritius, this event was moved to Mozambique with an expected execution date of August 2014. However, while planning was conducted, local capacity challenges dictated that the event be delayed until 2015 in Mozambique.

Namibia-Oil Spill Preparedness Discussions and Table Top Exercise (AFFY14018, \$34K). As a result of host nation issues, this event was replaced (following OSD approval) with a water capacity building workshop in Kenya in April 2014 for more than 35 participants. AFRICOM, drawing on expertise in Naval Facilities Command's Engineering and Expeditionary Warfare Center (NAVFAC's EXWC) and the U.S. Army Corps of Engineers, contributed to efforts to develop additional capacity in Kenya to plan for and execute small-scale projects that increase water availability. The workshop focused on promoting interagency cooperation, especially among the Kenya Ministry of Defense (MOD), its water and environment ministries, and its university community. Among other topics, MOD representatives were interested in enhancing their knowledge of erosion control and re-vegetation, which Kenya's military already does through its “environmental soldier” program. 


\section{U.S. Central Command (CENTCOM) Execution of DEIC Projects}

DUSD(I\&E) approved \$95,000 for one project in the CENTCOM AOR and \$57,000 for a second project eligible for reconsideration. A total of $\$ 98,000$ was ultimately provided to CENTCOM for one project, but then $\$ 2,620.25$ of this was returned; hence, final execution remained at $\$ 95,000$. While the event was intended to focus on basing sustainability and be executed in Tajikistan, political dynamics necessitated a substantial shift in both focus and location. As a result, CENTCOM executed one project in Kuwait, as described below.

Kuwait-Monitoring and Reporting of Illicit Discharges in the Ropme Sea Area (CEFY14107, \$95K). In September 2014, CENTCOM, with subject matter expertise from U.S. Navy Region Europe Africa Southwest Asia, and in cooperation with the Gulf Cooperation Council (GCC), sponsored a workshop to develop standardized procedures for monitoring and reporting illegal discharges of oil and other hazardous substances from ships. Some fifty participants from Bahrain, Kuwait, Oman, Qatar, Saudi Arabia, and the United Arab Emirates, as well as international organizations (e.g., the Marine Emergency Mutual Aid Center, or MEMAC, and the GCC) convened to determine existing environmental monitoring, maritime safety, and reporting capabilities of these countries and to begin work on developing standardized procedures. A follow-on workshop is planned to identify gaps in capabilities and continue work on standardized procedures. As the latter are developed, CENTCOM has noted they will help strengthen cooperation among environmental authorities, Navies, and Coast Guards of these countries. 



\section{U.S. European Command (EUCOM) Execution of DEIC Projects}

DUSD(I\&E) approved \$291,000 in projects for the EUCOM AOR and another $\$ 557,000$ in projects eligible for reconsideration. Actual funding for this AOR remained at the approved amount for the execution of eight projects. The executed projects in the EUCOM AOR and some of their key themes or findings are described below.

Multinational-MOD Meeting, Defense Network (DEFNET) (EUFY14202, $\$ 1 K)$. As in previous years, DEIC funding was used to support the travel costs associated with the participation of one subject matter expert at the annual DEFNET meeting, this one held in Lithuania in October 2013 with 19 European Union nations represented. DEFNET is an important mechanism for exchanges of information among defense environmental leaders on emerging European Union-related environmental matters that have implications for military forces located in Europe.

Multinational-Arctic Security Forces Roundtable (ASFR) 2014 (EUFY14207, $\$ \mathbf{1 4 4 K )}$. The fourth annual ASFR roundtable was held in Sortland, Norway, in August 2014. As in previous years, this roundtable received high-level support from the EUCOM command. Co-sponsored with the Norwegian Defence Force, this flag/general-officer level event brought together fifty participants from seven of the eight Arctic nations (Canada, Denmark, Finland, Iceland, Norway, Sweden, and the United States) as well as four observer nations (France, Germany, Netherlands, and United Kingdom). The focus in 2014 was on discussing issues and best practices related to operating in the Arctic (to include domain awareness and communication), identifying opportunities for enhanced cooperation, and charting the way ahead for the ASFR. ASFR's consistent purpose has been to promote regional understanding to enable dialogue and cooperation among the Arctic nations' militaries; to enhance multilateral Arctic security and safety operations; and to adapt to the changing environment and emerging missions.

Israel-Discussion on Best Practices for Environmental Risk Management and Baseline Studies (EUFY14209, \$3K). In May 2014, DEIC sponsored a familiarization visit for representatives from the Israeli Defense Forces and Ministry of Defense in the Washington, DC, area. Because some 40 percent of Israeli military bases will be new in the next 15 years, the emphasis during this exchange was on green building technologies, including a site visit to Fort Belvoir, VA. In addition, there was a presentation by a representative from NAVFAC EXWC on technologies developed or under development for potable water, sustainable infrastructure, and environmental remediation and 
monitoring. Costs paid for this effort through EUCOM were lower than originally expected as the only cost DEIC had to cover was the EUCOM representative's travel.

Azerbaijan-Caspian Sea Environmental Protection and Coastal Resiliency (EUFY14210, \$5K). A preliminary planning meeting for an oil spill and coastal resiliency workshop was held in Baku, Azerbaijan, in June 2014. The workshop could not be executed in FY14, however, due to host nation constraints. It is EUCOM's intention to execute the workshop in FY15, subject to the availability of FY15 funds.

Croatia-Coastal Resiliency and Regional Response Seminar II (EUFY14211, \$46K). This event was held in Split, Croatia, in June 2014. It was a follow-up effort to previous engagements with the Croatian Navy and Coast Guard in 2010, 2011, and 2013 and focused on a Command Post Exercise with approximately 30 Croatian Coast Guard representatives. The scenario-an off-shore maritime collision of passenger and commercial vehicles within territorial waters-demonstrated the need to fully coordinate the Coast Guard's plan with the National plan and encouraged stakeholders to further clarify roles and responsibilities of various agencies.

Latvia-Environmental Considerations in Military Operations (EUFY14215, \$31K). In April 2014, a three-person subject matter expert team led by EUCOM held a workshop in Riga, Latvia, with eight counterparts from the Latvian Ministry of Defense and armed forces. Both parties exchanged information about their environmental programs and experiences to help identify potential areas for collaboration, and the participants visited Latvia's main training base at Adazi. Topics included sustainable range management, environmental protection on land and at sea, environmental considerations in military deployments, and interagency cooperation. Because of Latvia's well-developed interagency cooperation and sustainable range management programs, a future effort could include U.S.-Latvian collaboration with other countries in Europe to strengthen their programs in these areas.

Montenegro-Environmental Considerations in Military Operations (EUFY14218, \$31K). In May 2014, a multinational workshop attended by thirteen MOD or military officers from Albania, Croatia, Kosovo, and Montenegro was held in Podgorica, Montenegro. The workshop offered an overview of defense-related environmental issues in Montenegro, U.S. environmental security engagement, sustainable range management, hazardous materials and waste management, environmental considerations for military bases, and interagency cooperation. Emphasis was on identifying common areas of interest for future multilateral cooperation.

Croatia_Field Water Generation Discussion (EUFY14224, \$30K). In June 2014, some 20 Croatian Army participants attended a workshop on field water purification in Zagreb, Croatia. The workshop offered additional familiarization with U.S. Army field water treatment equipment and procedures as a supplement to information provided in a 
2013 event on this topic. This workshop included a desktop exercise, requiring participants to apply the practices and procedures discussed. This initiative helped prepare Croatia for fielding its own equipment in 2014. 



\section{U.S. Northern Command (NORTHCOM) Execution of DEIC Projects}

NORTHCOM submitted two proposals, both of which the Advisory Group recommended funding for a total of $\$ 54,000$. Due to the $\mathrm{CR}$, however, funds were available to OSD later than expected, and NORTHCOM could not execute one of the two approved projects. The remaining project was executed for $\$ 32,000 .^{5}$

\section{Multinational-Shared Arctic Environment: Collaborative Approach} Workshop (NOFY14306, \$32K). A diverse U.S. team, comprising seventy-one representatives from federal and state governments as well as academia, industry, and nongovernmental organizations (NGOs), met with eight representatives from four other nations (Canada, Denmark, the Netherlands, and Norway) in Fairbanks, Alaska, in April 2014. The workshop included briefings on Arctic operations, activities, and research, as well as facilitated scenarios on environmental responses to military and civilian accidents in the Arctic region. The scenarios in particular sought to identify areas where government responses and cooperation need to be strengthened.

5 The amount of \$22,182.73 was returned to OSD(I\&E) during FY14 but was not reprogrammed for other DEIC uses, even though other CCMDs had confirmed they had requirements for any such returned funds. 



\section{U.S. Pacific Command (PACOM) Execution of DEIC Projects}

DUSD(I\&E) approved \$335,000 in projects for the PACOM AOR and another $\$ 89,000$ in projects eligible for reconsideration. Actual funding for this AOR was at the approved level of $\$ 335,000$ for two projects. The executed projects in the PACOM AOR and some of their key themes or findings are described below.

Multinational-Pacific Environmental Security Forum (PAFY14406, \$323K). The annual Pacific Environmental Security Forum was the fourth such event, this one with a regional focus on South Asia, and was co-hosted by the Maldives National Defence Force in June 2014. As in previous years, this forum received high-level support from the PACOM leadership. Seventy participants from Australia, Bangladesh, India, Maldives, Nepal, Sri Lanka, Thailand, and international organizations joined a U.S. interagency team to address ways to enhance military resiliency to climate change and to identify environmental activities that could be operationalized in South Asia. In particular, the forum focused on four themes: water security, waste management, resource protection, and energy. A site visit highlighted problems associated with coastal erosion and solid waste management, among other topics. Opportunities identified for the future included expanding oil spill response partnerships and partnering with local communities to reduce waste generation.

Maldives-Contingency Waste Management Operations in Island Environments - Siting Demonstration (PAFY14407, \$12K). PACOM, through U.S. Marine Corps Forces Pacific, provided subject matter expertise to the Maldives on waste management in an island environment. Because waste management in such an environment is difficult due to the scarcity of land, sensitive water resources, and long distances to alternate disposal and recycling sites, it is important to develop ways to reduce waste volume and exposure to contaminants, as well as to select proper siting for this activity. Through the sharing of this U.S. expertise, the Maldives National Defence Force is now better prepared to address these challenges. 



\section{U.S. Southern Command (SOUTHCOM) Execution of DEIC Projects}

DUSD(I\&E) approved \$384,000 in projects for the SOUTHCOM AOR and another $\$ 347,000$ in projects eligible for reconsideration. Actual funding for this AOR was approximately $\$ 383,000$ for seven projects. ${ }^{6}$ Three of the approved events could not be held, even at a reduced level of effort, due to delays in funding, scheduling changes, and changes within the planned host nation. This funding was subsequently reprogrammed to other SOUTHCOM-led environmental activities, without Advisory Group guidance, mainly in the form of support contracts, as described below. The executed projects in the SOUTHCOM AOR and some of their key themes or findings are described below.

Bilateral Meetings with Priority Countries to Establish Environmental Security Military Task Forces (SOFY14506, \$78K). This project supported SOUTHCOM and U.S. Army South (ARSOUTH) participation in a meeting with five Chilean military personnel in March 2014. The meeting also included the Texas National Guard, which is the lead for the State Partnership Program with Chile. Discussions focused on environmental programs in both countries, as well as working group sessions to develop collaborative plans for the next three to five years under the U.S.-Chile Defense Consultative Commission (DCC) in the areas of mission sustainability, operational risk management, and military adaptation to climate change. Because other engagements could not be executed as initially planned, remaining funds were placed on contract to support FY15 execution and FY16 planning of DEIC activities.

Multinational-Sustainability and Contingency Basing III-Energy, Water Waste (SOFY14509, \$21K). ARSOUTH conducted an engagement with a number of Army representatives from El Salvador, Guatemala, Honduras, Jamaica, and Trinidad \& Tobago in August 2014 in San Antonio, Texas. Topics addressed included: climate change impacts and adaptation opportunities for the military; environmental planning for military disaster response operations; net zero practices in operations; and the need to better integrate environmental considerations into multinational deployments. The latter issue was also the focus of a table top exercise.

Colombia-Military-Military-Civilian Operations and Water Sustainability in Remote Locations (SOFY14510, \$83K). This funding was used for a contract to assess water supply conditions, supply volumes, distribution networks, water quality, and

6 The amount of $\$ 1,343.83$ was returned to OSD(I\&E) at the end of FY14. 
recommended treatment systems at various remote Army battalion locations in Colombia. The Colombian Army will then use this information to develop projects to address the identified needs.

Honduras-Workshop on HAZMAT Management (Operation Martillo) (SOFY14513, \$2K). Because funds were not available in time for pre-planning meetings and because of subsequent scheduling conflicts, the DEIC portion of this project was considerably reduced. This funding supported SOUTHCOM participation in an August 2014 initial engagement led by the Defense Threat Reduction Agency to increase the awareness of Guatemala's first responders (both military and civilian) about handling hazardous materials (HAZMAT) and to improve their knowledge of each other's roles and capabilities in operating in a HAZMAT environment. More than 35 Guatemalan first responders participated in this session, which provided the first experience for many of them to consider issues associated with a HAZMAT situation.

Military Task Force Meetings on Defense Environmental Issues (SOFY14522, \$61K). A small amount of this funding was used to support SOUTHCOM's participation at the May 2014 meeting of the Inter American Defense Board (IADB) to present a report on the potential effects of environment and energy challenges for the military. The report will help shape future IADB actions on this topic. The Chairman of the IADB, LTG Werther Victor Araya, emphasized the importance of minimizing these challenges and sharing collective experiences and expertise. This report was developed as a result of collaboration with military partners from Chile, Colombia, El Salvador, and Trinidad \& Tobago through an on-line community of interest called the Environmental and Energy Collaboration Group (EECG). The remaining funds were used for contractor support for the EECG and report preparation.

Contractor Support for AARs, FY14 Execution and FY15 Planning (SOFY1424, \$27K). While several projects described above include contractor support, this additional amount of money was placed on contract to facilitate current year execution and planning for FY15 DEIC activities.

Partner Nation Military Capabilities Assessment (SOFY14525, \$111K). As part of the reprogramming of funds due to three events being cancelled, SOUTHCOM placed these funds on contract with Florida International University to produce research papers on Chile, Peru, Colombia, El Salvador, and Honduras. These papers are designed to identify military capacity within these five nations to utilize the information and expertise shared with them through DEIC activities. 


\section{Global and Program Support Projects Executed under the DEIC Program}

The ESOH office also uses DEIC money for global and programmatic support. In FY14, DUSD(I\&E) approved a total of \$36,000 and \$261,000, respectively, for these activities. Actual execution adhered to these same amounts.

Armed Forces Pest Management Board Herbicide Orange Inquiry Support (GLFY14601 \$36K). ESOH, through the Armed Forces Pest Management Board, continues to receive occasional inquiries concerning the presence and/or use of Herbicide Orange in the 1960s and 1970s; some of these inquiries are raised in the context of DOD's contacts with Vietnam, Japan, and South Korea. This project supported subject matter expertise to draft responses to such inquiries. While it did not include interactions with foreign nationals, ESOH lacks the in-house expertise to perform this work and determined that DEIC was the only available source of funding for this work.

Programmatic Tracking and Research Support to DEIC (IDA) (PRFY14701 \$261K). As part of its execution of the DEIC program, ESOH relies on FFRDC support from IDA to track DEIC activities throughout the year and to participate in several of the engagement initiatives. The funding covering these FFRDC expenses was greater than in the past, mainly because of IDA's increased role as a subject matter expert in several of the international engagements. During FY14, the engagements included multiple presentations at the EUCOM-led workshops in Latvia and Montenegro, organizing and hosting the familiarization visit with Israeli representatives from the Israeli Defense Force and MOD (all of these activities were described in chapter 4), and meetings with Sweden and Finland to map out future DEIC-supported activities. The FFRDC support also included the review presented in this document. 



\section{Program Assessment}

\section{A. FY14 Accomplishments}

The DEIC program continues to serve as a successful engagement tool with other nations on environmental issues. It contributes to the development of military-to-military relationships and interagency contacts, not only between the United States and the partner nation(s) but also within and among those partner nations.

There are a number of ways to assess the impact of the DEIC program. Quantifiable metrics and their FY14 results (to the extent they are available) are provided in Table 2.

Table 2. Quantifiable Metrics for the DEIC Program and FY14 Results

Type of Metric

\section{Related to quantity of foreign engagements}

- Percentage of DEIC projects involving interaction with $\quad 89 \%$ (24 of 27) other nations

- $\quad$ Percentage of DEIC funding spent on engagements $\quad 90 \%$ (\$1.494K of $\$ 1.668 \mathrm{~K})$ with other nations

- Ratio of the number of engagements with other nations to DEIC funding

\begin{tabular}{cll}
\hline$-\quad$ Number of foreign nationals engaged & $\approx 500$ \\
\hline$-\quad$ Number of foreign nations engaged $^{1}$ & $\begin{array}{l}57, \text { of which 16 participated in more } \\
\text { than one DEIC event }\end{array}$ \\
\hline
\end{tabular}

Related to leveraging funding from other sources

- Percentage of all DEIC projects that leveraged other $\quad 56 \%$ (15 of 27) funding

- Percentage of total spending on DEIC projects that $36 \%{ }^{2}$ was from other funding sources

${ }^{1}$ Another useful metric would be the number of engagements requested by other nations; this data is not, however, available for FY14.

${ }^{2}$ More than $\$ 942,000$ came from other sources of funding to support DEIC projects. Thus, the cost of all DEIC projects was approximately $\$ 2,610,000$. The only CCMD that did not utilize other sources of funding was CENTCOM. 
Less quantifiable, but no less important, results include:

- The President of Niger has sent an official request to the U.S. embassy for AFRICOM support to develop the ECOFORCE concept (as described in chapter 2), which was presented as part of a regional DEIC engagement.

- EUCOM continues to strongly support the high-level dialogue among the Arctic nations, the Arctic Security Forces Roundtable, as the premier engagement opportunity in this increasingly important region.

- PACOM continues to showcase the Pacific Environmental Security Forum (PESF) as part of its robust engagement activities in its AOR; it has also leveraged other funding to cover more than 40 percent of the costs of the event.

\section{B. Recommendations}

Despite the notable successes achieved by the DEIC program, there are a number of changes that, if incorporated, could enhance its effectiveness in future years. Above all, timelines should be tightened to facilitate execution, specifically:

- The Advisory Group meeting to review and recommend projects for the following fiscal year should be held no later than mid-September. This would allow OSD staff two weeks to prepare the paperwork for approval of the program by $\mathrm{ASD}(\mathrm{EI} \& \mathrm{E})$ so that the approval memo can be issued to the CCMDs the first week of October. This will then allow the CCMDs to know which activities have been approved at the very start of the fiscal year. If more staff time is necessary, the Advisory Group meeting should be moved to endAugust. Holding the Advisory Group meeting in October, as was done for the FY14 program, creates unnecessary delays in program execution.

- Assuming there continue to be CRs, OASD(EI\&E) should consider fully funding the DEIC program in the CR's first increment. Because of the international, collaborative nature of DEIC's work, it is essential for the CCMDs to have the full fiscal year to plan and execute the program. DEIC represents a very small financial investment; other programs within the EI\&E portfolio would be less seriously impacted by a delay of $\$ 1$ million in funding than DEIC. If such an option is not pursued, at a minimum each CCMD should receive at least some funding during the first quarter of the fiscal year. Even a small amount of funding would allow the CCMDs to begin planning their approved projects. 
There are strong arguments to be made for increasing DEIC's budget, rather than having it continue in a downward spiral. The CCMDs routinely submit valid DEIC projects that total approximately double the available funding. Thus, the demand signal clearly exists. And, the fact that some 65 percent of the projects executed in FY14 leveraged other sources of funding offers additional proof of DEIC's value. Furthermore, a recent OSD-sponsored workshop on the topic of CCMD climate security highlighted that DEIC is one of the very few programs available to the CCMDs to focus on climate change in their AORs. ${ }^{7}$ This workshop further called for exploring whether DEIC funding could be increased and provided more flexibility. For a program covering all the geographic CCMDs, DEIC needs a firm budget commitment, after all decrements are made, of at least $\$ 2$ million per year.

As noted earlier, DEIC projects are also required to meet certain criteria. Most importantly, the CCMDs are to engage with other nations, especially their defense or military personnel, and are to focus on defense-related environmental issues. The former criterion has not always been adhered to consistently, which is a factor that future Advisory Group meetings should take into consideration. For example,

- SOUTHCOM's project on remote water issues did not involve collaboration with Colombia, but rather preparation of a paper to be provided to Colombia. Generally in FY14, SOUTHCOM placed a considerable amount of its funds on contract. While some contract support is understandable, and more was apparently dictated by the inability to execute some projects due to funding delays, preparing papers (even as background information for future engagement) is a weak connection to the principles of international engagement.

- NORTHCOM's one project did involve foreign nationals, but the ratio of eight foreign participants to seventy-one U.S. participants is not a desirable one.

- The funding of a subject matter expert for the Armed Forces Pest Management Board to prepare responses to Herbicide Orange inquiries also has no direct engagement aspect.

While the DEIC program has always focused on environmental topics, the merger of Operational Energy with Installations \& Environment within OSD, creating the OASD(EI\&E), provides an opportunity to expand DEIC to include operational energy topics. Such an expansion is logical given that the DEIC program managers at the CCMDs often have operational energy as part of their portfolio, and many nations with whom they interact naturally view energy and environment as closely intertwined topics. If operational energy were added to DEIC's mandate, additional funds would be all the more crucial.

7 Combatant Command Climate Security Information Exchange, held at the Pentagon, 23-24 September 2014. 



\section{Appendix A \\ DEIC FY14 Call for Proposals and Meeting \\ Participation}




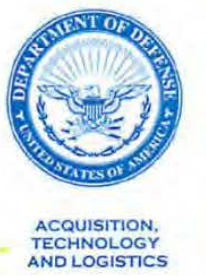

OFFICE OF THE UNDER SECRETARY OF DEFENSE

3000 DEFENSE PENTAGON

WASHINGTON, DC 20301-3000

MAY $10: 013$

MEMORANDUM FOR DEPUTY ASSISTANT SECRETARY OF DEFENSE

(STRATEGY)

DIRECTOR, JOINT STAFF

CHIEF OF STAFF, USAFRICOM

CHIEF OF STAFF, USCENTCOM

CHIEF OF STAFF, USEUCOM

CHIEF OF STAFF, USNORTHCOM

CHIEF OF STAFF, USPACOM

CHIEF OF STAFF, USSOUTHCOM

SUBJECT: Defense Environmental International Cooperation (DEIC) Program - FY14 Call for Proposals

This memo provides the schedule and guidance for submitting proposals for consideration in the DEIC Program allocation of FY14 resources. The DEIC Program provides expertise and funding to support security cooperation (e.g. build partnership capacity, reduce regional tensions, and sustain mission capability).

Eligible DEIC Program activities must include engaging with foreign defense ministries on environmental topics that have implications for military installations, training or operations. I encourage you to submit proposals that include civilian agencies, international organizations and non-government organizations.

The planned milestones for the DEIC FY14 proposal submission process are:

- No later than June 28, 2013 - Please submit FY14 DEIC Program proposals based on the guidance provided in the Attachment.

- We will meet with representatives from ODASD(Strategy) and the Office of the Chairman of the Joint Staff to evaluate the proposals.

- November 2013 - I will announce the approved FY14 DEIC Program.

My point of contact is Ms. Ninette Sadusky at (571) 372-6897 or Ninette.Sadusky@osd.mil.

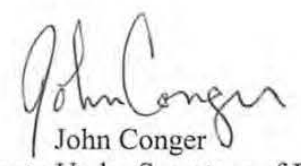

Acting Deputy Under Secretary of Defense (Installations and Environment)

Attachment:

As stated 


\section{DEIC Program - FY14 Proposal Submission Guidance}

Combatant Commands should consolidate their proposals and submit by June 28, 2013

for FY14 resource consideration. A cover memo signed out at the GFO/SES level is appropriate. They should be emailed to Susan Clark-Sestak at sclark@ida.org, with a copy to Mr. Bill

Mackie, Joint Staff at william.a.mackie.civ@mail.mil. The format of the proposals should be as follows:

1. Title of the proposal;

2. Organization (spell out) originating request, including DoD action officer, email address, and commercial and DSN phone number;

3. Description - Explain why this proposal and the country(ies) to be engaged are important and what the desired outcomes are.

a. General description of who, what, where, when, and how.

b. Why? - Cite support to specific objectives of the Guidance for the Employment of the Force and your Theater Campaign Plan. This is extremely important. The more context you provide, the more competitive your proposal is likely to be. We anticipate that this section of your proposal will be classified and should be submitted in a separate classified document to susan@ida.pentagon.smil.mil.

4. Documentation deliverables: For example, report, handbook, workshop, proceedings, etc.

5. Planned schedule for execution (include key planning meetings and events).

Please consider the " $80 / 20$ " rule - $80 \%$ obligation by end of July is mandatory.

No more than $20 \%$ of funding may remain unobligated after that date.

6. Resource requirements: Provide a detailed excel spreadsheet that identifies:

a. The amount of funds requested from the DEIC Program.

b. How funds will be spent (e.g., \# travelers, travel, per diem, publication costs, contractor support). DEIC Program is O\&M funding and subject to all restrictions of that appropriation.

c. Other resources that have been requested (e.g., Traditional Commander Activities, Warsaw Initiative Funds, Cooperative Threat Reduction, personnel, technology, etc.).

7. Additional Comments: Include any clarifying information that will aid our understanding in evaluating your proposals. This information should be clear, succinct, and proposal specific.

8. Priority: COCOMs must prioritize their proposal requests if submitting more than one.

Compliance with all current guidance governing travel and conferences (if applicable) is required. 



\section{Appendix B DEIC FY14 Spreadsheet}

As described in chapter 1, this spreadsheet presents the complete list of projects proposed by the CCMDs for DEIC funding in FY14. The Advisory Group identified projects that should have highest priority (funding for which is listed in the "approved" column), then those that were also valid projects but could not be funded due to budget constraints (listed in the "reconsider" column). The amount of funding expended for each project is listed in the "actual" column, and the amount and source of other funding is listed in the "leveraged funds" column. ${ }^{1}$

1 See chapter 1 for more detail on how the Advisory Group evaluated each project and allocated funding. 


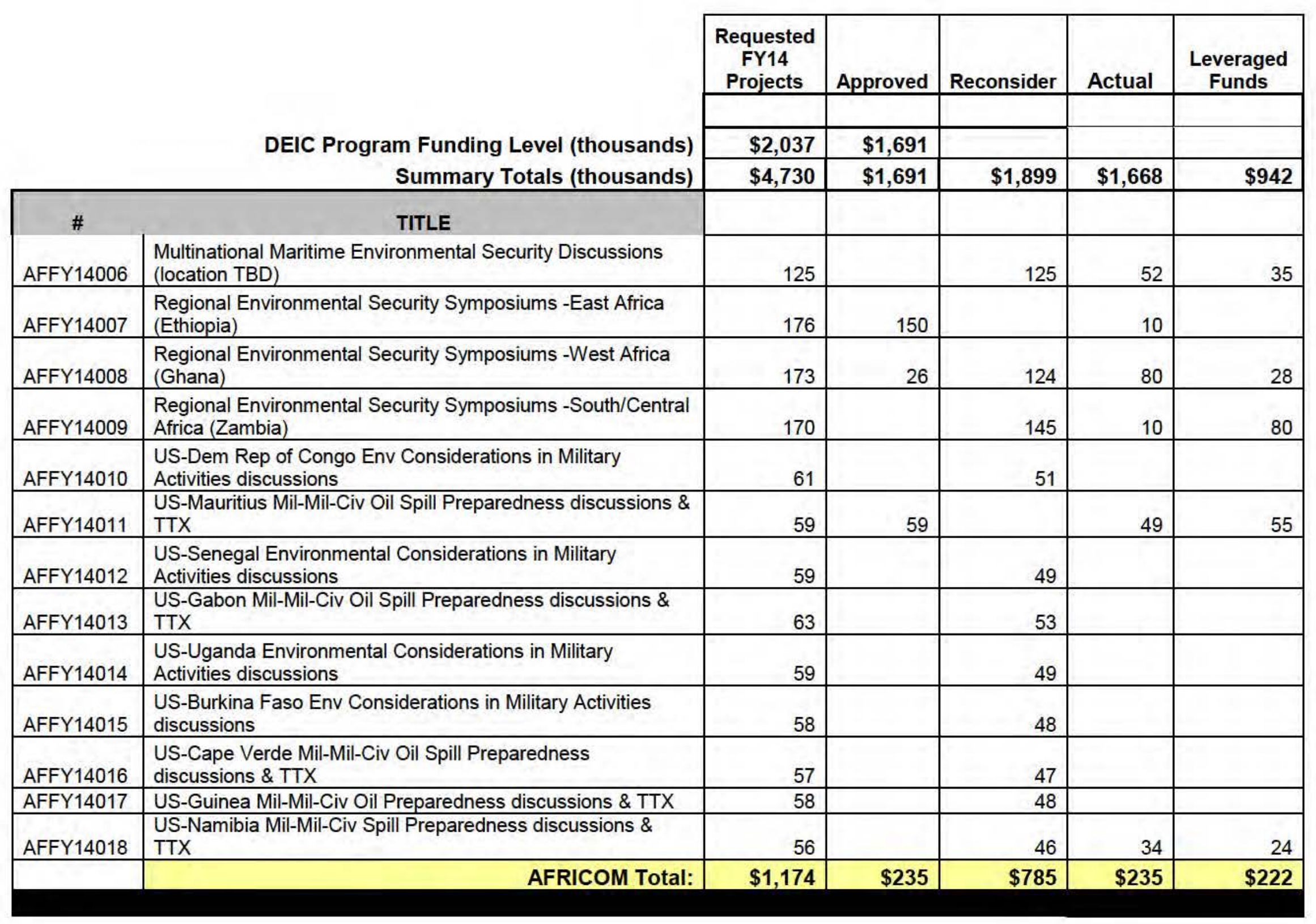




\begin{tabular}{|c|c|c|c|c|c|c|}
\hline CEFY14106 & $\begin{array}{l}\text { US-Egypt Basing Sustainability-Ensuring Deployable Force } \\
\text { thru Env Risk Mgt }\end{array}$ & 57 & & 57 & & \\
\hline CEFY14107 & $\begin{array}{l}\text { US-Tajikistan Basing Sustainability-Ensuring Deployable } \\
\text { Force thru Risk Mgt }\end{array}$ & 95 & 95 & & $\$ 95$ & \\
\hline & CENTCOM Total: & $\$ 152$ & $\$ 95$ & $\$ 57$ & $\$ 95$ & $\$ 0$ \\
\hline EUFY14201 & $\begin{array}{l}\text { US-Israeli Defense Env Engagement (OUSD(AT\&L)/Intl } \\
\text { Cooperation Bilateral) }\end{array}$ & 15 & see below & 15 & & \\
\hline EUFY14202 & $\begin{array}{l}\text { Defense network (DEFNET) - Multinational MoD mtg-US } \\
\text { OSD Representation }\end{array}$ & 2 & 1 & & 1 & \\
\hline EUFY14203 & NATO SPS (Zero Footprint, Green Acquisition) & 14 & & 14 & & \\
\hline EUFY14204 & U.S.-Finland-Sweden Trilateral & 4 & & 4 & & \\
\hline EUFY14206 & NATO-Russia Council on Field Water & 45 & 45 & 0 & 0 & \\
\hline EUFY14207 & $\begin{array}{l}\text { Arctic Security Forces Roundtable } 2014 \text { (bilateral \& } \\
\text { multilateral mtgs + table top) }\end{array}$ & 137 & 135 & 2 & 144 & 27 \\
\hline EUFY14208 & $\begin{array}{l}\text { Climate Change Impacts on Infectious Disease Prevalence } \\
\text { (Russia) }\end{array}$ & 42 & & 42 & & \\
\hline EUFY14209 & $\begin{array}{l}\text { US-Israel Discussion on Best Practices for Env Risk Mgt and } \\
\text { Baseline Studies }\end{array}$ & 50 & 35 & 15 & 3 & \\
\hline EUFY14210 & $\begin{array}{l}\text { Caspian Sea Environmental Protection and Coastal } \\
\text { Resiliency (Azerbaijan) }\end{array}$ & 49 & 39 & 0 & 5 & \\
\hline EUFY14211 & $\begin{array}{l}\text { Coastal Resiliency and Regional Response Seminar II } \\
\text { (Croatia) }\end{array}$ & 46 & 36 & 6 & 46 & 5 \\
\hline EUFY14212 & $\begin{array}{l}\text { Visualizing Implications of Climate Change on Mil Activity and } \\
\text { Relations II (Bulgaria) }\end{array}$ & 45 & & 39 & & \\
\hline EUFY14213 & $\begin{array}{l}\text { Adriatic Environmental Protection and Coastal Resiliency } \\
\text { (Albania) }\end{array}$ & 36 & & 32 & & \\
\hline EUFY14214 & $\begin{array}{l}\text { US-Serbia Sustainable Range Management Best Practices } \\
\text { Discussion }\end{array}$ & 32 & & 32 & & \\
\hline EUFY14215 & Environmental Considerations in Military Operations (Latvia) & 31 & & 31 & 31 & 3 \\
\hline EUFY14216 & $\begin{array}{l}\text { US-Moldova Discussions Best Practices for Pesticides \& } \\
\text { Hazardous Matl Handling }\end{array}$ & 41 & & 41 & & \\
\hline EUFY14217 & $\begin{array}{l}\text { Multinational-Sava River Modeling: Military Adaptation to } \\
\text { Climate Change Effects }\end{array}$ & 42 & & 37 & & \\
\hline EUFY14218 & US-Montenegro Env Considerations in Military Operations & 31 & & 31 & 31 & 10 \\
\hline EUFY14219 & $\begin{array}{l}\text { US-Israel Discussions on Best Practices for Base } \\
\text { Sustainability }\end{array}$ & 35 & 0 & 0 & & \\
\hline
\end{tabular}




\begin{tabular}{|c|c|c|c|c|c|c|}
\hline EUFY14220 & $\begin{array}{l}\text { US-Kosovo Best Practices Hazardous Material Handling \& } \\
\text { Storage Workshop }\end{array}$ & 32 & & 32 & & \\
\hline EUFY14221 & $\begin{array}{l}\text { US-Azerbaijan Best Practices Hazardous Material Handling \& } \\
\text { Storage Workshop }\end{array}$ & 31 & & 31 & & \\
\hline EUFY14222 & $\begin{array}{l}\text { Multilateral Discussion on Mil Adaptation to Climate Change: } \\
\text { Permafrost Impacts on Infrastructure II (Denmark) }\end{array}$ & 40 & & 37 & & \\
\hline EUFY14223 & $\begin{array}{l}\text { US-Albania Green Maintenance Program Development } \\
\text { Discussions }\end{array}$ & 28 & & 26 & & \\
\hline EUFY14224 & US-Croatia Field Water Generation Discussion & 30 & & 30 & 30 & 13 \\
\hline \multirow[t]{2}{*}{ EUFY14225 } & $\begin{array}{l}\text { US-Israel Discussion on Env Considerations in Base Site } \\
\text { Selection }\end{array}$ & 60 & & 60 & & \\
\hline & EUCOM Total: & $\$ 918$ & $\$ 291$ & $\$ 557$ & $\$ 291$ & $\$ 58$ \\
\hline NOFY14306 & $\begin{array}{l}\text { Shared Arctic Environment: Collaborative Approach } \\
\text { Workshop(Multinational) }\end{array}$ & 66 & 36 & 0 & 32 & \\
\hline \multirow[t]{2}{*}{ NOFY14307 } & ESOH Risk Mgt Workshop (Multinational) & 20 & 18 & 0 & & \\
\hline & NORTHCOM Total: & $\$ 86$ & $\$ 54$ & $\$ 0$ & $\$ 32$ & $\$ 0$ \\
\hline PAFY14401 & $\begin{array}{l}\text { Trilateral Environmental Security Cooperation (Australia- } \\
\text { Canada-US + UK) }\end{array}$ & 40 & 23 & & & \\
\hline PAFY14406 & $\begin{array}{l}\text { Pacific Environmental Security Forum (bilaterals and } \\
\text { multinational discussions) }\end{array}$ & 312 & 312 & 0 & 323 & 536 \\
\hline PAFY14407 & $\begin{array}{l}\text { Contingency Waste Mgt Operations in Island Environment- } \\
\text { Siting Demonstration }\end{array}$ & 87 & & 12 & 12 & 24 \\
\hline PAFY14408 & $\begin{array}{l}\text { US-Thailand Maritime Monitoring Awareness mtgs \& table top } \\
\text { exercise }\end{array}$ & 77 & & 77 & & \\
\hline PAFY14410 & Sustainable Water Mgmt and Safety under...Climate Change & 73 & 0 & 0 & & \\
\hline PAFY14411 & Waste to Energy Technology Demo-Maldives & 320 & 0 & 0 & & \\
\hline PAFY14412 & $\begin{array}{l}\text { Waste to Energy Technology Demo-Cobra Gold Exercise } \\
\text { (Thailand) }\end{array}$ & 150 & 0 & 0 & & \\
\hline \multirow[t]{2}{*}{ PAFY14413 } & $\begin{array}{l}\text { Waste to Energy Technology demo-Balikatan Exercise } \\
\text { (Philippines) }\end{array}$ & 150 & 0 & 0 & & \\
\hline & PACOM Total: & $\$ 1,209$ & $\$ 335$ & $\$ 89$ & $\$ 335$ & $\$ 560$ \\
\hline
\end{tabular}




\begin{tabular}{|c|c|c|c|c|c|c|}
\hline SOFY14501 & $\begin{array}{l}\text { US - Chilean Defense Consultative Committee - Energy \& } \\
\text { Environment Submit }\end{array}$ & 20 & See below & & & \\
\hline SOFY14506 & $\begin{array}{l}\text { US Bilateral Mtgs } 6 \text { Priority countries-Establish Env Security } \\
\text { Mil Task Forces }\end{array}$ & 78 & 78 & 0 & 78 & 20 \\
\hline SOFY14507 & $\begin{array}{l}\text { US-El Salvador Air Force Base-Solar Energy \& Water } \\
\text { Sustainability mtg }\end{array}$ & 78 & & 78 & & \\
\hline SOFY14508 & $\begin{array}{l}\text { US-Honduras Navy Base-Water, Waste \& Energy } \\
\text { Sustainability mtg }\end{array}$ & 6 & 6 & 0 & 0 & \\
\hline SOFY14509 & $\begin{array}{l}\text { Multinational-Sustainability and Contingency Basing III- } \\
\text { Energy, Water, Waste }\end{array}$ & 89 & 74 & 15 & 21 & 54 \\
\hline SOFY 14510 & $\begin{array}{l}\text { US-Colombia-Mil-Mil-Civ Ops \& Water Sustainability in } \\
\text { Remote Locations }\end{array}$ & 60 & 60 & 0 & 83 & \\
\hline SOFY14511 & $\begin{array}{l}\text { Improved Integration of Existing Technology in Disaster } \\
\text { Response }\end{array}$ & 47 & & 47 & & \\
\hline SOFY14513 & Workshop on HAZMAT Management (e.g. Operation Martillo) & 42 & 42 & 0 & 2 & \\
\hline SOFY14514 & $\begin{array}{l}\text { US Navy-El Salvador Air Force Discussions on Best Practices } \\
\text { for Waste Water Treatment at Comalapa Joint Base }\end{array}$ & 76 & & 54 & & \\
\hline SOFY14515 & US-Brazil-Discussions on Joint Efforts in Disaster Monitoring & 44 & & 44 & & \\
\hline SOFY14517 & $\begin{array}{l}\text { US-Chile Joint Doctrine on Env Considerations in Mil Ops } \\
\text { (Chilean DCC) }\end{array}$ & 63 & 63 & 0 & 0 & \\
\hline SOFY14519 & Discussions on Env Responsible Solid/Liquid Waste Disposal & 145 & & 65 & & \\
\hline SOFY14520 & $\begin{array}{l}\text { Discussions on Env Sustainability in Exercise Related } \\
\text { Construction Projects }\end{array}$ & 38 & 0 & 0 & & \\
\hline SOFY14522 & $\begin{array}{l}\text { Military Task Force Mtgs on Defense Environmental Issues } \\
\text { (via APAN) }\end{array}$ & 61 & 61 & 0 & 61 & 28 \\
\hline SOFY14523 & $\begin{array}{l}\text { US-Costa Rica Discussions on Env Disaster Risk Mgt-MIL } \\
\text { Support to CIV Authorities }\end{array}$ & 44 & & 44 & & \\
\hline SOFY14524 & Contractor support for AARs, FY14 execution and FY15 plan & & & & 27 & \\
\hline \multirow[t]{2}{*}{ SOFY14525 } & Partner Nation Military Capabilities Assessment & & & & 111 & \\
\hline & SOUTHCOM Total: & $\$ 891$ & $\$ 384$ & $\$ 347$ & $\$ 383$ & $\$ 102$ \\
\hline GLFY14601 & AFPMB Herbicide Orange Inquiry Support & 100 & 36 & 64 & 36 & \\
\hline \multirow[t]{2}{*}{ GLFY14602 } & AFPMB Herbicide Orange Inquiry Support-part 2 & & 61 & & & \\
\hline & GLOBAL Total: & $\$ 100$ & $\$ 97$ & $\$ 64$ & $\$ 36$ & $\$ 0$ \\
\hline \multirow[t]{2}{*}{ PRFY14701 } & Programmatic Tracking and Research Support to DEIC (IDA) & 200 & 200 & 0 & 261 & \\
\hline & PROGRAM SUPPORT Total: & $\$ 200$ & $\$ 200$ & $\$ 0$ & $\$ 261$ & $\$ 0$ \\
\hline
\end{tabular}





\section{Appendix C Illustrations}

\section{Figures}

Figure 1. Amount and Timing of DEIC Funds Released to the CCMDs (Thousands) .......2

Figure 2. DEIC Annual Funding Levels: CCMD Requests vs. Actual ..............................3

Figure 3. DEIC Program FY14 Spending, by Area of Responsibility..............................5

\section{Tables}

Table 1. DEIC Program Funding Returned, by CCMD, and Reasons for the Return.........1

Table 2. Quantifiable Metrics for the DEIC Program and FY14 Results .........................23 



\section{Appendix D Bibliography}

Barrett, Major General Mark A., USAF. “Memorandum on FY14 Defense Environmental International Cooperation (DEIC) Program Proposals.” U.S. European Command, 28 June 2013.

Clark-Sestak, Susan L. and Ashley Neese Bybee. Review of the Fiscal Year 2013 (FY13) Defense Environmental International Cooperation Program. D-5129. Alexandria, VA: Institute for Defense Analyses, February 2014.

Conger, John. "Memorandum on Defense Environmental International Cooperation (DEIC) Program-FY14 Call for Proposals.” Acting Deputy Under Secretary of Defense for Installations and Environment, 10 May 2013.

Conger, John. "Memorandum on Defense Environmental International Cooperation (DEIC) FY14 Approved Program.” Acting Deputy Under Secretary of Defense for Installations and Environment, 22 November 2013.

Cook, Captain Richard, USN. "Memorandum on U.S. Africa Command FY14 Defense Environmental International Cooperation (DEIC) Program Proposals.” U.S. Africa Command, 24 July 2013.

Horst, Major General Karl R, USA. "Memorandum on FY14 Defense Environmental International Cooperation (DEIC) Program Call for Proposals.” U.S. Central Command, 27 June 2013.

Luckey, Major General Charles D, USA. "USNORTHCOM FY14 Defense Environmental International Cooperation (DEIC) Proposals.” U.S. Northern Command, 28 June 2013.

McLeod, Brigadier General Mark M., USAF. "Memorandum on U.S. Pacific Command FY14 Defense Environmental International Cooperation (DEIC) Program Proposals.” U.S. Pacific Command, 26 June 2013.

Nowland, Brigadier General Mark C., USAF. "Memorandum on United States Southern Command (USSOUTHCOM) Defense Environmental International Cooperation (DEIC) Program FY14 Proposals.” U.S. Southern Command, 2 July 2013. 



\section{Appendix E Abbreviations}

AAR

AFRICOM

ACSS

AOR

APAN

APRI

ARSOUTH

ASD

ASFR

CCMD

CENTCOM

CR

DCC

DEFNET

DEIC

DOD

DUSD

EECG

$\mathrm{EI} \& \mathrm{E}$

ERDC

$\mathrm{ESOH}$

EUCOM

EXWC

FFRDC

FY

GCC

HAZMAT

IADB

I\&E

IDA

MEMAC

MOD
After Action Report

U.S. Africa Command

Africa Center for Strategic Studies

Area of Responsibility

All Partners Access Network

Asia Pacific Regional Initiative

U.S. Army South

Assistant Secretary of Defense

Arctic Security Forces Roundtable

Combatant Command

U.S. Central Command

Continuing Resolution

Defense Consultative Commission

Defense Network

Defense Environmental International Cooperation

Department of Defense

Office of the Deputy Under Secretary of Defense

Environmental and Energy Collaboration Group

Energy, Installations and Environment

U.S. Army Engineer Research and Development

Center

Environment, Safety and Occupational Health

U.S. European Command

Expeditionary Warfare Center

Federally Funded Research and Development Center

Fiscal Year

Gulf Cooperation Council

Hazardous Material

Inter American Defense Board

Installations and Environment

Institute for Defense Analyses

Marine Emergency Mutual Aid Center

Ministry of Defense 
NAVFAC

NGO

NORTHCOM

OSD

PACOM

PESF

SOUTHCOM

TCA

TSC

UNEP

USAID
Naval Facilities Command

Non-Governmental Organization

U.S. Northern Command

Office of the Secretary of Defense

U.S. Pacific Command

Pacific Environmental Security Forum

U.S. Southern Command

Traditional Commander's Activity

Theater Security Cooperation

United Nations Environmental Program

U.S. Agency for International Development 
Public reporting burden for this collection of information is estimated to average 1 hour per response, including the time for reviewing instructions, searching existing data sources, gathering and maintaining the data needed, and completing and reviewing this collection of information. Send comments regarding this burden estimate or any other aspect of this collection of information, including suggestions for reducing this burden to Department of Defense, Washington Headquarters Services, Directorate for Information Operations and Reports (0704-0188), 1215 Jefferson Davis Highway, Suite 1204, Arlington, VA 22202-4302. Respondents should be aware that notwithstanding any other provision of law, no person shall be subject to any penalty for failing to comply with a collection of information if it does not display a currently valid OMB control number. PLEASE DO NOT RETURN YOUR FORM TO THE ABOVE ADDRESS.

1. REPORT DATE (DD-MM-YYYY)

XX-05-2015

2. REPORT TYPE

Final

4. TITLE AND SUBTITLE

Review of the Fiscal Year 2014 (FY14) Defense Environmental International Cooperation (DEIC) Program
3. DATES COVERED (From - To)

Feb 2015 - May 2015

5a. CONTRACT NO.

W91WAW-12-C-0017

5b. GRANT NO.

5c. PROGRAM ELEMENT NO(S).

5d. PROJECT NO.

5e. TASK NO.

AM-6-2557

5f. WORK UNIT NO.

7. PERFORMING ORGANIZATION NAME(S) AND ADDRESS(ES) Institute for Defense Analyses

4850 Mark Center Drive

Alexandria, VA 22311-1882

9. SPONSORING/MONITORING AGENCY NAME(S) AND ADDRESS(ES)

10. SPONSOR'S/MONITOR'S ACRONYM(S)

ASD(EI\&E)

Office of the Assistant Secretary of Defense

Energy, Installations and Environment

4800 Mark Center Drive

11. SPONSOR'S/MONITOR'S REPORT NO(S).

Alexandria, VA 22350-3605

12. DISTRIBUTION/AVAILABILITY STATEMENT

Approved for public release; distribution is unlimited.

13. SUPPLEMENTARY NOTES

\section{ABSTRACT}

The Defense Environmental International Cooperation (DEIC) program is a tool for the Office of the Secretary of Defense and the Combatant Commands (CCMDs) to use as part of their security cooperation engagement activities with other nations. The projects it supports focus on defense-related, environmental themes, with special priority on projects that promote mission sustainment, innovative approaches to environment, safety and occupational health (ESOH) risk management, and/or building capacity for strategic partnerships. IDA reviewed the execution of the Fiscal Year 2014 (FY14) DEIC program, assessed the program's performance for that year, and recommended metrics to evaluate and changes to implement to enhance the program's future execution.

\section{SUBJECT TERMS}

Environmental cooperation; international engagement; CCMD security cooperation engagement activities; Defense Environmental International Cooperation (DEIC); metrics

16. SECURITY CLASSIFICATION OF:

a. REPORT

Unclass.

\begin{abstract}
b. ABSTRACT
\end{abstract}
Unclass.
17. LIMITATION OF 18 . NUMBER OF ABSTRACT

SAR

\section{PAGES}

54 19a. NAME OF RESPONSIBLE PERSON

Mr. Shah A. Choudhury

19b. TELEPHONE NUMBER (Include Area Code) 571-372-6809 


